\title{
Ecthyma gangrenosum in a patient with febrile pancytopenia
}

\section{Samia Mrabat, Hanane Baybay, Ryme Dassouly, Zakia Douhi, Sara Elloudi, Fatima Zahra Mernissi}

\author{
Department of Dermatology, University Hospital Hassan II, Fes, Morocco
}

Corresponding author: Samia Mrabat, MD, E-mail: samiamrabat91@gmail.com

Ecthyma gangrenosum (EG) is a cutaneous infection most commonly associated with Pseudomonas bacteremia and usually occurring in immunocompromised patients [1]. The infection progresses sequentially from a maculopapular rash to hemorrhagic bullae, then to necrotic ulcerations with surrounding erythema [2]. Herein, we report a case of ecthyma gangrenosum in an immunologically compromised patient.

A65-year-old female was admitted to the oncohematology department for febrile pancytopenia. Blood work revealed severe thrombocytopenia at $15,000 / \mathrm{mm}^{3}$ ), an absolute neutrophil count of 180 cells/ $\mathrm{mm}^{3}$, and anemia. A sternal bone marrow puncture found $15 \%$ of plasma cells. Four days after the admission, the patient had a painful, quickly extending lesion on the abdomen. She described erythema that progressed to pustules, then ulcerations. On general clinical evaluation, the patient was feverish at $40^{\circ} \mathrm{C}$. A dermatological examination revealed the presence of a $6 \mathrm{~cm}$ purpuric patch on the left flank with a central necrotic eschar (Fig. 1). The diagnosis of ecthyma gangrenosum was reached and the patient was treated with ceftazidime and vancomycin. Unfortunately, having gone into septic shock, the patient died one week later.

\section{Consent}

The examination of the patient was conducted according to the principles of the Declaration of Helsinki.

The authors certify that they have obtained all appropriate patient consent forms, in which the patients gave their consent for images

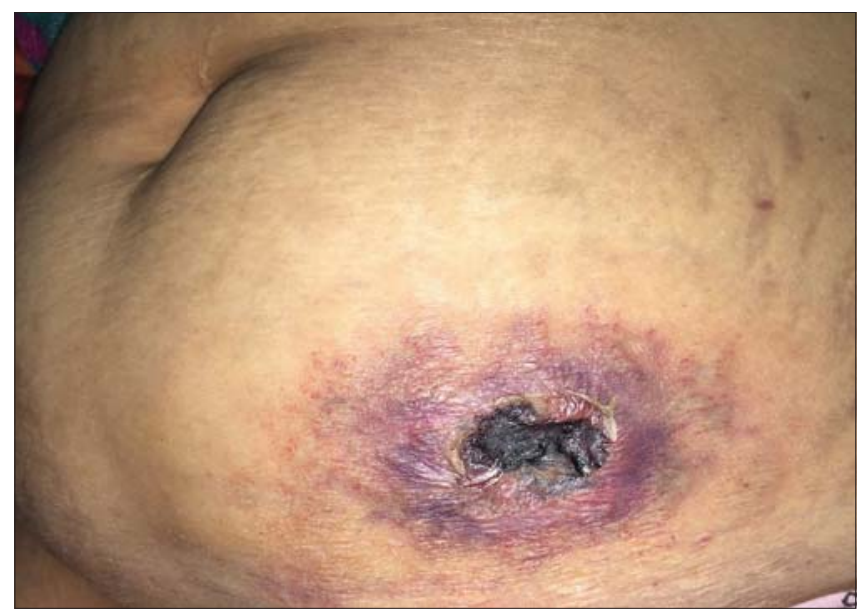

Figure 1: Purpuric patch with irregular borders and a central necrotic eschar.

and other clinical information to be included in the journal. The patients understand that their names and initials will not be published and due effort will be made to conceal their identity, but that anonymity cannot be guaranteed.

\section{REFERENCES}

1. Khoo T, Ford F, Lobo Z, Psevdos G. One thing after another: Ecthyma gangrenosum. Am J Med. 2018;131:510-1.

2. Abdou A, Hassam B. [Ecthyma gangrenosum]. Pan Afr Med J. 2018;30:95.

Copyright by Samia Mrabat, et al. This is an open access article distributed under the terms of the Creative Commons Attribution License, which permits unrestricted use, distribution, and reproduction in any medium, provided the original author and source are credited. Source of Support: Nil, Conflict of Interest: None declared. 